Martynas Vasiliauskas

Katedra Prawa Publicznego

Uniwersytet Wileński

\title{
CZY OMBUDSMAN MOŻE BYĆ „RYWALEM” SĄDU JAKO TRZECIEJ WŁADZY?
}

\section{Wstęp}

Zagadnienie, czy ombudsman (rzecznik praw obywatelskich) jest „rywalem" sądu jako jednej z trzech władz w państwie ${ }^{1}$, może być rozpatrywane wieloaspektowo: poprzez porównanie pełnomocnictw sądu i rzecznika praw obywatelskich; analizę ustalonej praktyki współpracy sądu i rzecznika praw obywatelskich oraz charakterystykę czynności sądu i rzecznika praw obywatelskich podczas rozstrzygania sporów itd.

Celem niniejszej pracy jest przedstawienie pewnego, dość kontrowersyjnego aspektu ewentualnej konkurencyjności (o ile ona ma miejsce) rzeczników praw obywatelskich i sądów. Może się komuś wydawać, że taki aspekt relacji pomiędzy rzecznikami praw obywatelskich a sądami jest w ogóle niemożliwy, niedopuszczalny czy wręcz skandaliczny. Albo że poruszana kwestia jest błędna sama w sobie i formułowanie takiego pytania nie ma sensu. Decyduję się jednak podjąć tego zadania i nie tylko dlatego, że prawie dziesięć lat pracuję w tej dziedzinie. Poruszać ten problem należy przede wszystkim dlatego, że może to wpłynąć na poprawę działalności sądów i zwiększenie zaufania społeczeństwa wobec nich. Poza tym sam fakt stawiania takiego pytania mógłby zaktywizować do dyskusji w tej kwestii, czego dotąd unikano, tak jakby był to temat tabu. Chce się wierzyć, że doprowadziłoby to do podjęcia konkretnych racjonalnych decyzji.

Nasuwa się pytanie: co jest ważniejsze - niezależność sądów czy prawa człowieka? Inaczej mówiąc, czy sądy, zasłaniając się zasadą własnej nieza-

${ }^{1}$ Art. 5 Konstytucji Republiki Litewskiej głosi: „Władzę państwową w Litwie sprawują: Sejm, prezydent i rząd państwa, Sąd". 
leżności, nie naruszają praw człowieka? Może się wydawać niezrozumiałe, $\mathrm{w}$ jaki sposób te pytania wiążą się z prowadzoną w niniejszej pracy analizą relacji pomiędzy sądami i rzecznikami praw obywatelskich, dlatego na początku warto krótko omówić, jakie są kompetencje rzeczników praw obywatelskich, a jakie sądów, ze szczególnym uwzględnieniem roli rzeczników praw obywatelskich, bowiem w kwestii kompetencji sądów w zasadzie nie ma dyskusji. Później, analizując orzeczenia Konstytucji Republiki Litewskiej (dalej: Konstytucji) i orzecznictwo Sądu Konstytucyjnego Republiki Litewskiej (dalej: SKRL), spróbuję odpowiedzieć na pytanie dotyczące wyższości zasady niezależności sądów nad prawami człowieka. Na zakończenie przedstawię konkretne propozycje dotyczące ewentualnego udoskonalenia Konstytucji (rzecz jasna, nie znaczy to, że są one naprawdę konieczne).

\section{Kompetencje sądów i rzeczników praw obywatelskich}

Zasadniczą rolą sądu jako trzeciej władzy - jest sprawowanie wymiaru sprawiedliwości. W części 1. art. 109 Konstytucji stwierdza się: „Wymiar sprawiedliwości na Litwie sprawują wyłącznie sądy”2. SKRL akcentuje: „Sprawowanie wymiaru sprawiedliwości - to funkcja sądów, decydująca o miejscu tej władzy w systemie instytucji władzy państwowej oraz statusie sędziów. Żadna inna instytucja państwowa lub osoba urzędowa nie może pełnić tej funkcji”3.

Kompetencje sądów są określone zwięźle i jasno. Rzecz jasna, można byłoby dyskutować nad tym, co to jest wymiar sprawiedliwości, w jaki sposób jest on realizowany itd., ale to zagadnienie wykracza poza zakres niniejszej pracy. Jasne jest również to, że jednym z aspektów sprawowania wymiaru sprawiedliwości jest ochrona praw człowieka. SKRL podkreśla:

[...] Sądy, sprawując wymiar sprawiedliwości, mają obowiązek zapewnienia realizowania praw określonych w Konstytucji i innych aktach prawnych, zagwarantowania wyższości sądów, ochrony praw i wolności człowieka ${ }^{4}$.

A więc sądy, sprawując wymiar sprawiedliwości, gwarantują, żeby prawa człowieka nie były naruszane i aby zwracano na nie uwagę (aspekt prewencyjny, który w przypadku sądu jest bardziej teoretyczny i postrzegany tylko w takim sensie, że osoba, która naruszyła prawo osobiste innej osoby, wie, że może za to zostać osądzona; same sądy nie zajmują się aktywną pre-

\footnotetext{
${ }^{2}$ Konstytucja RL, „Valstybès žinios” 1992, nr 33-1014.

${ }^{3}$ Uchwała SKRL z dn. 21 grudnia $1999 \mathrm{r}$.

${ }^{4}$ Tamże.
} 
wencją praw człowieka). W przypadku gdy prawa człowieka zostały naruszone, sądy sprawując wymiar sprawiedliwości, sięgają po wszystkie możliwe środki w celu przywrócenia naruszonych praw (aspekt reagowania, na którym w zasadzie opiera się cała działalność sądów). Tak więc realnie rzecz biorąc, do ochrony praw człowieka sądy mogą włączyć się dopiero wtedy, gdy już doszło do ich naruszenia i tylko w tym przypadku, gdy osoba, której prawa zostały naruszone, zgłosi to. A więc powiedzenie, że sądy chronią prawa człowieka, w zasadzie oznacza próbę przywrócenia już naruszonych praw, a nie zapobiegania potencjalnym naruszeniom.

Jakie są kompetencje rzecznika praw obywatelskich i w jaki sposób to stanowisko jest związane z prawami człowieka? Na początku warto przypomnieć, że na Litwie rzecznik praw obywatelskich nazywany jest kontrolerem, a główny rzecznik parlamentarny - kontrolerem sejmowym (zgodnie z ustawą, obecnie wyznaczani są dwaj kontrolerzy sejmowi). Poza tym na Litwie jest też kilku rzeczników praw obywatelskich o specjalnym przeznaczeniu, takich jak kontroler ds. ochrony praw dziecka oraz kontroler ds. równouprawnienia, ale analiza ich działalności wykracza poza zakres tej pracy.

Kompetencje rzeczników praw obywatelskich (kontrolerów), podobnie jak sądów, zostały określone w Konstytucji: „Skargi obywateli dotyczące nadużywania władzy przez urzędników państwowych i samorządowych (z wyjątkiem sędziów) oraz biurokracji badają kontrolerzy sejmowi. Mają oni prawo proponowania sądowi zwolnienia z pełnionych obowiązków winnych urzędników" (część 1 art. 73 Konstytucji) ${ }^{5}$. Orzecznictwo SKRL w zasadzie nie omawia kwestii dotyczących kontrolerów sejmowych. SKRL bardzo krótko i zwięźle wspomina o miejscu kontrolerów sejmowych w strukturze instytucji państwowych i określa podstawowe (rzecz jasna, nie wszystkie) aspekty ich kompetencji tylko w jednej uchwale.

SKRL podkreśla, że kontrolerzy sejmowi nie są zaliczani ani do władzy ustawodawczej, ani wykonawczej, ani sądowniczej ${ }^{6}$. Takie stwierdzenie bez wątpienia pozwala mówić o wyjątkowym statusie rzecznika praw obywatelskich, a także potwierdza, że tych rzeczników można zaliczyć do przedstawicieli tzw. czwartej władzy ${ }^{7}$. Rzecz jasna, kwestia czwartej władzy jest również bardzo ciekawa i wymagająca dyskusji, ale w niniejszej pracy ograniczymy się jedynie do stwier-

${ }^{5}$ LR Konstitucija, „Valstybès žinios” 1992, nr 33-1014.

${ }^{6}$ Uchwała SKRL z dn. 13 grudnia $2004 \mathrm{r}$.

${ }^{7}$ Ową czwartą władzę można byłoby nazwać „władzą nadzorczą”. Taką nazwę sugerują też inne, oprócz kontrolerów sejmowych, instytucje wymienione w uchwale SKRL, nienależące do żadnej z trzech klasycznych władz: Kontrola Państwowa (audytor), prokuratura, bank litewski, służba bezpieczeństwa, dowódca armii oraz Najwyższa Komisja Wyborcza. Wszystkie te instytucje nie uczestniczą w ustawodawstwie, w sprawowaniu wymiaru sprawiedliwości, nie należą też do władzy wykonawczej, ich podstawowym przeznaczeniem jest nadzorowanie (w wielu przypadkach również prewencyjne) konkretnych aspektów działalności państwa. 
dzenia, że według jednej z teorii, czwarta władza istnieje i że rzecznicy praw obywatelskich w strukturze instytucji państwowej są zaliczani właśnie do niej.

W kwestii kompetencji kontrolerów sejmowych SKRL stwierdził:

Praca systemu służb państwowych, instytucji władzy musi być zorganizowana w ten sposób, aby osoby zwracające się do instytucji władzy, urzędników państwowych nie doświadczały samowoli, nadużyć, biurokracji, aby ich sprawy były rozpatrywane i rozstrzygane bez odwlekania. [...] Niedopuszczalne jest, aby praca instytucji państwowych i samorządowych była organizowana w ten sposób, że osoba, która zwraca się do instytucji państwowej lub samorządowej z konkretną sprawą, była zmuszona zwracać się w tej samej sprawie ponownie dlatego, że po pierwszym skierowaniu, chociaż było ono uzasadnione i spełniało wszystkie wymogi określone w aktach prawnych (łącznie z proceduralnymi), rozpatrywanie tej sprawy nie zostało podjęte ${ }^{8}$.

Uogólniając i upraszczając powyższy cytat określający kompetencje kontrolerów sejmowych, można stwierdzić, że kontrolerzy sejmowi muszą zagwarantować, aby sprawy interesantów były odpowiednio rozstrzygane w instytucjach władzy. Odpowiednie rozstrzyganie sprawy, według SKRL, to takie, w którym nie ma nadużyć, odwlekań, samowoli czy biurokracji. Należy podkreślić wagę wspomnianego cytatu z SKRL oraz fakt, że zostały w nim wymienione nie tylko instytucje władzy (między innymi sądy są jedną z instytucji władzy), ale też urzędnicy państwowi (jak wiadomo, pomocnicy sędziów, sekretarze posiedzeń sądowych, pracownicy kancelarii i innych pododdziałów w sądzie są urzędnikami państwowymi, przyjmowanymi na służbę według tych samych zasad jak urzędnicy każdej innej instytucji). Ten aspekt będzie ważny dla naszych dalszych wywodów w kwestii konkurencyjności sądów i rzeczników praw obywatelskich.

Tak więc chociaż SKRL dotąd nie omawiał szczegółowo kwestii rzeczników praw obywatelskich, trzeba przyznać, że w istocie trafnie określił ich kompetencje. Początki instytucji rzecznika praw obywatelskich sięgają początku XVIII wieku, gdy w 1713 roku król Szwecji Karol XII postanowił wprowadzić urząd kanclerza sprawiedliwości. Do jego obowiązków należało nadzorowanie, aby urzędnicy państwowi przestrzegali aktów prawnych i pełnili swoje obowiązki ${ }^{9}$. Po upływie prawie stu lat szwedzki parlament (Riksdag) również zdecydował wprowadzić urząd rzecznika praw obywatelskich i zlecić mu nadzorowanie tego, jak urzędnicy państwowi pełnią swoje obowiązki (bowiem kanclerz sprawiedliwości kontrolował tylko tych urzędników, których wyznaczał król (rząd) ${ }^{10}$. Po upływie kolejnych prawie stu lat

${ }^{8}$ Uchwała SKRL z dn. 13 grudnia $2004 \mathrm{r}$.

${ }^{9}$ B. Wieslander, The Parliamentary Ombudsman in Sweden, The Bank of Sweden Tercentenary Foundation and Gidlunds Bokförlag, 2005, s. 13.

${ }^{10}$ Tamże, s. 14-15. 
idea rzecznika praw obywatelskich powoli zaczęła się rozszerzać. Obecnie ten urząd istnieje w większości krajów na świecie.

Podstawową przyczyną pojawienia się rzecznika praw obywatelskich była potrzeba zapewnienia, aby urzędnicy państwowi trzymali się aktów prawnych i pełnili swoje obowiązki. Właśnie to zostało zaakcentowane w uchwale SKRL: kontrolerzy sejmowi mają nadzorować, czy urzędnicy odpowiednio rozpatrują sprawy interesantów. Takie tłumaczenie przeznaczenia rzecznika praw obywatelskich uchodzi za klasyczne. Ale w ciągu ponad dwustu lat działalność rzeczników w wielu państwach uzyskała zupełnie nowy charakter. Profesor G. Kucsko-Stadlmayer z uniwersytetu w Wiedniu, która dokonała analizy porównawczej europejskich instytucji rzecznika praw obywatelskich, twierdzi:

W miarę poszerzania się celu nowych instytucji rzecznika praw obywatelskich, rozrosły się również kompetencje samych rzeczników. Najważniejszym założeniem ich pracy stała się ochrona praw człowieka. Ta ochrona została utrwalona nie tylko w konstytucjach państwowych, ale też zaakcentowana na poziomie międzynarodowym - poprzez ratyfikację Europejskiej Konwencji Praw Człowieka. Często rzecznikom praw obywatelskich wyznacza się wyjątkowe zadanie zagwarantowania w systemie prawnym swojego kraju wszechstronnej realizacji praw człowieka, odciążenia prawa osób do zwracania się do sądów oraz składania propozycji wydawcom ustaw dotyczących ochrony praw człowieka, zachowania się wobec osób poszkodowanych albo po prostu w sprawie polepszenia warunków życiowych. Te dodatkowe funkcje stwarzają warunki do tego, aby obrona praw człowieka stała się podstawą działalności instytucji. W ten sposób rola rzecznika praw obywatelskich w polityce państwowej pozwala osiągnąć znacznie więcej niż w przypadku nadzoru ze strony innych urzędników ${ }^{11}$.

Pozwala to wyróżnić jeszcze jeden aspekt kompetencji rzecznika praw obywatelskich, jakim jest ochrona praw człowieka. Jak twierdzi dr Augustinas Normantas, profesor Uniwersytetu Wileńskiego, były sędzia Sądu Konstytucyjnego, a obecnie kierownik instytucji kontrolerów sejmowych, pozwala to „nazywać rzecznika praw obywatelskich obrońcą praw człowieka przed naruszeniami ze strony urzędników albo nadzorcą urzędników, w celu ochrony praw człowieka"12.

Była już mowa o tym, że sądy reagują na naruszanie praw człowieka już po fakcie i tylko wtedy, gdy osoba zgłasza się sama w tej sprawie. Tymczasem rzecznicy praw obywatelskich mogą reagować nie tylko na te naruszenia, które już miały miejsce, ale (i to jest właśnie zasadniczy aspekt działalności rzeczników i ich wyjątkowość!) też stosować wszelkie możliwe środki w celu

${ }^{11}$ G. Kucsko-Stadlmayer, The Competence of European Ombudspersons - A Survey, European Ombudsman Meeting, IOI - European Region. General Assembly, June 11-13, Vienna. Proceedings: Federal Ministry of Education, Science and Culture, Vienna 2006, s. 17-18.

${ }^{12}$ A. Normantas, Ombudsmenas - pareigūnų prievaizdas ar „mogaus teisiu gynéjas?, [w:] Parlamentas ir valstybinès valdžios instituciju sq̨ranga. Liber amicorum Česlavui Jurâenui, kolektyvinė monografija, Mykolo Romerio Universitetas, Vilnius 2008, s. 270. 
zapobieżenia naruszeniu praw człowieka. Rzecznicy mają bardzo skuteczną broń, której nie posiadają sądy, czyli badanie ex officio. Analiza prof. G. Kucsko-Stadlmayer wykazała, że w regionie europejskim prawie $85 \%$ rzeczników praw obywatelskich jest upoważnione do prowadzenia badań z własnej inicjatywy ${ }^{13}$. Autorka podkreśla, że wykonując badania z własnej inicjatywy, rzecznicy praw obywatelskich mogą analizować problemy systemowe, które dotyczą licznej grupy osób; takich badań nie trzeba legitymować formalnie, to znaczy, aby je wykonać, nie jest potrzebne podanie lub wskazanie. Poza tym badania wykonane $\mathrm{z}$ własnej inicjatywy znacznie wzmacniają charakter prewencyjny działalności rzeczników praw obywatelskich ${ }^{14}$. Litwa pod tym względem nie jest wyjątkiem. Art. 13 Ustawy o kontrolerach sejmowych nadaje kontrolerom pełnomocnictwo w kwestii podejmowania badań z własnej inicjatywy, jedynie z przekonania wewnętrznego o potencjalnym naruszeniu praw człowieka ${ }^{15}$. Poza tym rzecznicy praw obywatelskich mogą wykonać badania z własnej inicjatywy, nawet rozpatrując skargi nie są oni zobowiązani do odpowiadania wyłącznie na pytania wyrażone w skardze, wręcz przeciwnie, mogą wyjść poza ten zakres i wypowiedzieć się w dowolnej kwestii, która ich zdaniem może służyć ochronie praw człowieka. Kontrolerzy sejmowi, w zasadzie nie badając skargi, mogą na przykład wypowiedzieć się w dowolnej kwestii dotyczącej praw człowieka ${ }^{16}$.

Reasumując, można stwierdzić, że ochrona praw człowieka jest zasadniczym kierunkiem działalności zarówno sądów, jak też rzeczników praw obywatelskich, ale ci pierwsi działają retrospektywnie, to znaczy reagują na wydarzenia, które miały miejsce w przeszłości, i wybiórczo, to znaczy tylko przy okazji (na przykład zgłoszenia osoby), której nie można przekroczyć. Natomiast ci drudzy działają prewencyjnie, to znaczy dążą do zapobieżenia potencjalnym naruszeniom i z własnej inicjatywy, czyli sami podejmują się badania aktualnych kwestii w określonym zakresie.

\section{Czy niezależność sądów stoi wyżej niż prawa człowieka?}

Po omówieniu (w miarę możliwości) zagadnienia dotyczącego kompetencji sądów i rzeczników praw obywatelskich, a także ich stosunku wobec praw człowieka, możemy przejść do pytania, co stoi wyżej: niezależność są-

\footnotetext{
${ }^{13}$ G. Kucsko-Stadlmayer, dz. cyt., s. 490.

${ }^{14}$ Tamże, s. 21.

${ }^{15}$ Ustawa kontrolerów sejmowych RL.

${ }^{16}$ Ustawa kontrolerów sejmowych RL, uchwała nr 19, część 1, punkt 2.
} 
dów czy prawa człowieka? Poszukiwanie odpowiedzi na to pytanie należy rozpocząć od omówienia pojęcia niezależności sądów.

Na początku trzeba zaznaczyć, że niezależność sądów jest powszechnie uznawaną zasadą. Art. 10 Powszechnej Deklaracji Praw Człowieka z 1948 roku stanowi: „Każdy ma jednakowe prawo do tego, aby określając jego prawa i obowiązki oraz wnosząc przeciwko niemu oskarżenie, jego sprawę sprawiedliwie i publicznie zbadał niezależny i bezstronny sąd". Art. 6 Europejskiej Konwencji Praw Człowieka i Ochrony Podstawowych Wolności głosi: „Kiedy jest rozpatrywana kwestia naruszenia praw i obowiązków konkretnej osoby o charakterze cywilnym lub postawiono ją w stan oskarżenia, taka osoba ma prawo, aby w ciągu minimalnego okresu czasu jej sprawa została rozpatrzona publicznie i sprawiedliwie, zgodnie z przepisami, przez powołany niezależny i bezstronny sąd". W art. 47 Karty Praw Podstawowych UE jest mowa o tym, że „każda osoba ma prawo, aby jej sprawę w ciągu możliwie krótkiego czasu publicznie i sprawiedliwie rozpatrzył, zgodnie z przepisami, powołany niezależny i bezstronny sąd".

W Konstytucji RL są dwa artykuły związane z niezawisłością sądów. Art. 31 Konstytucji stanowi: „Osoba oskarżona o dokonanie przestępstwa ma prawo, aby jej sprawę publicznie i sprawiedliwie rozpatrzył niezależny i bezstronny sąd”, a art. 109 dodaje: „Sędziowie i sądy, pełniąc sprawiedliwość, są niezależni"17.

Jak widać, wszystkie podstawowe dokumenty utrwalające prawa człowieka akcentują niezależność sądów. Pozwala to wysunąć wniosek, że niezależność sądów jest potrzebna do tego, żeby prawa człowieka w rzeczywistości były bronione. $\mathrm{W}$ istocie tylko niezależny i bezstronny sąd może zagwarantować wszystkim osobom skuteczną i prawdziwą obronę posiadanych przez nich praw. Akcentuje to w swoim orzeczeniu również SKRL, twierdząc, że niezależność sądów jest „koniecznym warunkiem ochrony praw i wolności człowieka” ${ }^{18}$ i że „gwarancje niezależności sądów są konieczne przede wszystkim dlatego, żeby były zagwarantowane prawa i wolności człowieka"19.

Można więc sądzić, że niezależność sądów sama w sobie jest prawem człowieka. Inaczej mówiąc, każda osoba ma prawo do tego, aby jego sprawę rozpatrzył niezależny i bezstronny sąd. Potwierdza to również SKRL: „Zasada niezależności sądów wiąże się z orzeczeniami art. 6 Europejskiej Konwencji Praw Człowieka, które utwierdzają prawo osoby do niezależnego i bezstronnego sądu"20.

\footnotetext{
${ }^{17}$ Konstytucja RL, „Valstybės žinios” 1992, nr 33-1014.

${ }^{18}$ Uchwała SKRL z dn. 13 grudnia 2004 r.

${ }^{19}$ Uchwała SKRL z dn. 6 grudnia $1995 \mathrm{r}$.

${ }^{20}$ Uchwała SKRL z dn. 13 grudnia $2004 \mathrm{r}$.
} 
To znaczy, że pytanie o to, co stoi wyżej - niezależność sądów czy prawa człowieka, należy sformułować inaczej: co stoi wyżej - prawo człowieka do niezależnego sądu czy prawa człowieka w ogóle? Rzecz jasna, że jedno z praw człowieka nie może stać wyżej od wszystkich innych praw człowieka. Jest to sprzeczne z zasadami logiki; części składowe podmiotu nie mogą być ważniejsze niż sam podmiot. Możemy porównywać ze sobą różne obiekty albo części składowe tego samego obiektu, ale nie możemy porównywać samego obiektu i jego części. Takie porównywanie jest logicznie błędne i niemożliwe. Na przykład nie możemy pytać, co stoi wyżej - Katedra Prawa Konstytucyjnego czy Wydział Prawa? Bez Wydziału Prawa nie byłoby Katedry Prawa Konstytucyjnego, podobnie jak bez prawa nie byłoby prawa konstytucyjnego, a bez prawa człowieka nie byłoby prawa człowieka do niezależnego sądu. Są to po prostu nieporównywalne rzeczy: część nie może być ważniejsza czy wyższa niż całość. Staje się oczywiste, że prawa człowieka, jako całość, są sprawą znacznie ważniejszą niż jedno z praw człowieka. To znaczy, że jedno konkretne prawo nie może być przesłaniane, aby pomniejszyć lub naruszyć inne prawa.

Trzeba przyznać, że przynajmniej na Litwie niezależność sądów jest pojmowana jako ich przywilej, chroniący sądy od jakiejkolwiek zewnętrznej oceny sądów i sędziów i stwarzający możliwość sądom i sędziom niezwracania uwagi na inne prawa człowieka. Inaczej mówiąc, niezależność sądów jest oceniana jako zabezpieczenie, jako granica, której nie można przekroczyć, nie zważając na to, że sędziowie odwlekają rozpatrywanie spraw, nie przestrzegają terminów procesowych, niestosownie zachowują się podczas rozpraw sądowych, a administracja sądowa nie udostępnia osobom na czas dokumentów związanych z procesem, nie udziela niezbędnej informacji, nie przestrzega wymagań dotyczących ochrony danych osobowych itd. Można byłoby wymienić jeszcze więcej sytuacji, gdy w sądach dochodzi do naruszenia praw człowieka, ale nawet tych wymienionych wcześniej wystarczy, aby stwierdzić, że sądy i sędziowie, podobnie jak każda inna instytucja władzy lub urzędnik, mogą naruszyć prawa człowieka. Najważniejsze jest to, że w tej sytuacji nie mówimy o sprawowaniu wymiaru sprawiedliwości, gdyż wspomniane sytuacje obejmują działania sądów i sędziów, które nie należą do wymiaru sprawiedliwości. Nikt nie podważa faktu, że sąd powienien rozpatrywać spory zgodnie ze swoim wewnętrznym przekonaniem, własnym pojmowaniem sprawiedliwości oraz wymagań dotyczących aktów prawnych. Jest to kompetencja sądu i naprawdę nikt w tym przypadku nie ma prawa wskazywać sądowi, w jaki sposób należy rozstrzygać spory. Ale pełniąc tę podstawową funkcję, sądy i sędziowie wykonują wiele innych działań: kontaktują się z ludźmi, w ustalonym terminie wykonują działania procesowe, udzielają informacji, udostępniają dokumenty itp. W tym przypadku 
wszyscy mamy prawo żądać od sądu stosowania aktów prawnych, szanowania osób biorącycyh udział w procesie oraz tego, aby jego działania nie naruszały praw człowieka. Takie wymagania wobec sądu są uznawane nie za naruszenie ich niezależności, lecz odwrotnie - za przejaw niezależności i czynnik wzmacniający autorytet sądu. Co będzie, jeżeli sąd, zasłaniając się niezależnością, nie będzie zwracał uwagi na człowieka i jego prawa, będzie unikał jakiejkolwiek odpowiedzialności? W ten sposób sąd tylko pomniejszy swój autorytet i osłabi zaufanie. Taki sąd będzie nie tylko „niezależny”, ale też autokratyczny, zamknięty i oderwany od realnego świata. Taki sąd będzie realizował nie sprawiedliwość, ale własną wolę. Wątpliwe, aby były nam potrzebne takie sądy, które błędnie pojmują swoją niezależność.

SKRL stwierdza, że „głównym aspektem, którym należy kierować się w ocenie niezależności sędziego i sądów, jest świadomość, że niezależność nie jest przywilejem, a jednym z najważniejszych obowiązków sędziego i sądu, który wynika z zagwarantowanego przez Konstytucję prawa człowieka do posiadania w sporze niezależnego arbitra" ${ }^{21}$. Podkreśla też, że „konstytucyjne i inne ustawowe gwarancje niezależności sędziego i sądów, podobnie jak zasady etyki sędziowskiej, są podstawą zaufania ludzi wobec bezstronności i obiektywizmu sądu jako arbitra sporów sądowych"22. Wspomniane cytaty potwierdzają wniosek, że niezależność sądów jest gwarancją nie tylko ochrony praw człowieka, ale też zaufania wobec sądów oraz tego, że decyzje wynikające z Konstytucji i innych aktów prawnych, reglamentujące niezależność sądów, powinny być gwarancją nie tylko ochrony praw człowieka, ale też zaufania wobec sądów, oraz że sądy nie mogą być zamknięte i nie zwracać uwagi na ustalone w aktach prawnych wymagania wobec nich. SKRL twierdzi również, że „system gwarancyjny niezależności sądów nie tworzy żadnych przesłanek, którymi zasłaniając się sędzia mógłby unikać odpowiedniego pełnienia swoich funkcji, niedbale rozpatrywać sprawy, nieetycznie zachowywać się wobec uczestniczących w sprawie osób, naruszać prawa człowieka i poniżać jego godność. Sędziowie powinni strzec honoru swojego zawodu i prestiżu"23. Tak więc niezależność sądów nie może być zasłoną dla niedbałego rozpatrywania spraw, pozwalającą zachowywać się nieetycznie lub w inny sposób naruszać prawa człowieka.

Warto podkreślić, że gwarancje niezależności sędziów SKRL dzieli na trzy grupy: 1) nietykalności ważności upoważnienia; 2) nietykalności osobistej oraz 3) o charakterze społecznym (materialnym) ${ }^{24}$. Żadna z tych gwarancji niezależności sędziów w żaden sposób nie łączy się z podanymi przez

\footnotetext{
${ }^{21}$ Uchwała SKRL z dn. 6 grudnia $1995 \mathrm{r}$.

22 Tamże.

${ }^{23}$ Uchwała SKRL z dn. 13 grudnia $2004 \mathrm{r}$.

${ }^{24}$ Uchwała SKRL z dn. 6 grudnia $1995 \mathrm{r}$.
} 
nas wcześniej przykładami dotyczącymi nieprzestrzegania terminów, niestosownego zachowania się wobec stron biorących udział w sprawie i in. Pozwala to wyciągnąć wniosek, że niezależność sądów nie obejmuje jednak takich sytuacji, gdy sędziowie unikają wykonywania swoich obowiązków, niedbale rozpatrują sprawy lub w inny sposób naruszają prawa człowieka. To znaczy, że te aspekty działalności sądów i sędziów muszą być nadzorowane, musi istnieć odpowiedni mechanizm nadzoru działalności sądów i sędziów, który byłby swoistą gwarancją tego, że sądy i sędziowie będą stosowali się do wymagań wynikających z aktów prawnych i nie będą naruszali praw człowieka. Każda osoba musi wiedzieć, do kogo ma się zgłosić i co robić, jeżeli sąd jako instytucja albo sędzia zachowują się niestosownie.

Według SKRL nadzorem działalności sądów i sędziów powinni zająć się sami sędziowie, tzn. odpowiednie pochodne samorządu sędziowskiego: „System samoregulacji i samorządu władzy sądowniczej musi zagwarantować, żeby sędziowie stosownie pełnili swoje obowiązki, aby każde bezprawne i nieetyczne zachowanie sędziego zostało odpowiednio ocenione"25. Taki model nadzoru działalności sędziów jest możliwy przynajmniej teoretycznie, ale powstaje pytanie, na ile jest on realny, tzn. na ile sami sędziowie są bezstronni i zainteresowani w tym, aby każdy przypadek niestosownego zachowania się sędziego został zbadany? Mądrość ludowa głosi, że kruk krukowi oka nie wykole, a więc czy może jeden sędzia bezstronnie, obiektywnie i niezależnie oceniać działalność innego sędziego? Podobnie jak każdy ma prawo do tego, aby jego „sprawę" rozpatrywał niezależny i bezstronny sąd, każdy ma też prawo do tego, aby jego „skargę” związaną z działalnością sędziego również rozpatrywano niezależnie i bezstronnie. Rzecz kuriozalna, ale wygląda na to, że $w$ takim przypadku niezależne i bezstronne rozpatrywanie sprawy jest niemożliwe, gdyż stosowny element pochodny samorządności sędziów, rozpatrujący taką skargę nie jest ani niezależny, ani bezstronny. Tak więc chociaż od sądów i sędziów wymagamy, aby byli niezależni oraz przy pomocy wszelkich możliwych środków prawnych staramy się zagwarantować tę niezależność, to rozpatrując skargi dotyczące działalności swoich kolegów, sędziowie nie są niezależni.

Oczywiście nasuwa się pytanie, czy Konstytucja nie przewiduje innego, niezależnego i bezstronnego modelu oceny działalności sędziego, niezwiązanego ze sprawowaniem wymiaru sprawiedliwości? Analiza Konstytucji oraz orzecznictwa SKRL pozwala twierdzić, że taki model jest przewidziany, chodzi mianowicie o rzecznika praw obywatelskich. Jak już była mowa o tym wcześniej, jedyny artykuł Konstytucji wspominający o rzeczniku praw obywatelskich stanowi:

${ }^{25}$ Uchwała SKRL z dn. 13 grudnia 2004 r. 
Skargi obywateli dotyczące nadużyć oraz biurokracji ze strony urzędników państwowych i samorządowych (z wyjątkiem sędziów) badają kontrolerzy sejmowi. Mają oni prawo proponowania sądowi zwolnienia z pełnienia obowiązków winnych urzędników. Pełnomocnictwa kontrolerów sejmowych ustala ustawa ${ }^{26}$.

Czym są nadużycie i biurokracja, określa Ustawa kontrolerów sejmowych:

Nadużycia - to takie działania urzędnika albo brak jego działania, kiedy nadane mu upoważnienia są wykorzystywane niezgodnie z ustawami czy innymi aktami prawnymi lub w celu osiągnięcia własnej korzyści czy za namową innych osób (wykorzystywanie stanowiska służbowego, kierowanie się chęcią zemsty, zazdrością, karierowiczowstwo, bezprawne udzielanie usług itd.), jak również takie działania urzędników, kiedy są przekraczane pełnomocnictwa lub dochodzi do samowoli ${ }^{27}$.

Biurokracja - to taka działalność urzędnika, kiedy zamiast rozstrzygania spraw stosuje się w zasadzie niepotrzebne lub wymyślone formalności, bez uzasadnienia odmawia się rozpatrywania zagadnień, które są w gestii urzędnika, zwleka się z podejmowaniem decyzji czy pełnieniem obowiązków lub nieodpowiednio się je sprawuje (odmawia się informowania osoby o jej prawach, świadomie udziela się błędnych lub nieodpowiednich porad itd.). Biurokracją jest też taka praca urzędnika, gdy nie przestrzega się lub źle przestrzega ustaw albo innych aktów prawnych ${ }^{28}$.

Nie ma wątpliwości co do tego, że niestosowne i nieetyczne zachowanie się wobec stron biorących udział w sprawie, niedbałe rozpatrywanie spraw, nieszanowanie honoru człowieka, nieprzestrzeganie terminów, nieudzielanie informacji i inne czynności oznaczają, że pełnomocnictwa nadane sędziemu i sądowi są stosowane niezgodnie z przeznaczeniem, gdy sędzia lub sąd dokonują samowoli, zwlekają z podejmowaniem decyzji, odmawiają osobom udzielenia informacji na temat ich praw, źle wypełniają ustawy - a to wszystko odpowiada pojęciom nadużycia i biurokracji. To oznaczałoby, że pełnomocnictwa nadane kontrolerom sejmowym pozwalają im oceniać taką działalność sędziów. Ale w Konstytucji jest zastrzeżenie: „skargi związane z nadużyciem i biurokracją [...] urzędników (z wyjątkiem sędziów) [...]”. Śmiem twierdzić, że to zastrzeżenie nie oznacza absolutnego zakazu badania przez kontrolerów sejmowych działania sędziów, jest ono dodatkową gwarancją niezależności sądów. To zastrzeżenie akcentuje, że kontrolerzy sejmowi nie mogą wtrącać się do sprawowania wymiaru sprawiedliwości, jest to bowiem wyjątkowa funkcja sądu, ale nie ogranicza możliwości badania przez kontrolerów sejmowych innej działalności sędziów, niezwiązanej ze sprawowaniem wymiaru sprawiedliwości.

${ }^{26}$ Ust. 1 i 2 art. 73 Konstytucji RL. LR Konstitucija, „Valstybès žinios” 1992, nr 33-1014.

${ }^{27}$ Ust. 4. art. 2 Ustawy kontrolerów sejmowych RL, Lietuvos Respublikos Seimo kontrolieriu ịstatymas, „Valstybės žinios” 1998, nr 110-3024; 2004, nr 170-6238.

${ }^{28}$ Część 1 art. 2 Ustawy kontrolerów Sejmu RL, Lietuvos Respublikos Seimo kontrolierių istatymas, „Valstybès žinios” 1998, nr 110-3024; 2004, nr 170-6238. 
Rzecz jasna, w szerszym sensie można twierdzić, że dowolne działanie, które wykonuje sąd lub sędzia, jest częścią składową sprawowania wymiaru sprawiedliwości (nawet wysyłanie decyzji sądu lub wyznaczanie posiedzenia sądowego w ciągu określonego czasu od momentu zgłoszenia się stron uczestniczących w sprawie), ale poprzez takie tłumaczenie sprawowania wymiaru sprawiedliwości znowu stawiamy część składową wyżej niż całość. Nie może być wątpliwości, że każda osoba ma prawo do tego, aby w jej sprawie zadziałał wymiar sprawiedliwości (nawet jeżeli jest jej nieprzychylny), ale tak samo ma też prawo do tego, żeby nawet podczas sprawowania wymiaru sprawiedliwości były szanowane i gwarantowane wszystkie jej prawa. Na przykład nawet jeżeli człowiek został osądzony za morderstwo, to nie daje to prawa sędziemu poniżać tę osobę w obecności innych stron biorących udział w sprawie lub drwić z niej.

Tak więc można twierdzić, że Konstytucja wręcz zobowiązuje kontrolerów sejmowych do badania skarg dotyczących nadużyć i biurokracji sędziów. Poza tym warto też podkreślić, że o ile w kwestii możliwości badania przez kontrolerów sejmowych spraw dotyczących nadużyć i biurokracji sędziów potrzebne były dodatkowe argumenty, o tyle w sprawie możliwości badania przez nich działalności urzędników pracujących w sądzie w ogóle nie powinno być żadnych wątpliwości. Urzędnicy pracujący w sądzie są przyjmowani na stanowiska $\mathrm{w}$ takim samym trybie, jak każdy inny urzędnik instytucji państwowej, stawia się wobec nich takie same wymagania, jak wobec innych urzędników. To, że ci urzędnicy pracują w sądzie, nie może być żadnym usprawiedliwieniem dla tego, aby nie badać ich spraw, gdyż urzędnicy sądowi nie sprawują wymiaru sprawiedliwości. Poza tym w systemie zarządzania państwem są oni traktowani jako urzędnicy państwowi, tak samo jak wszystkie inne osoby pracujące w instytucjach władzy.

Wprawdzie wystarczyłby sam tylko art. 73 Konstytucji, aby uzasadnić prawo kontrolerów sejmowych do badania działalności sędziów, ale można podać jeszcze kilka dodatkowych argumentów. Art. 5 Konstytucji potwierdza: „Instytucje władzy służą ludziom”29. Wcześniej była mowa o tym, że właśnie kontrolerzy sejmowi są instytucją, która nadzoruje, jak instytucje władzy służą ludziom, rozstrzygają sprawy i czy nie naruszają przy tym praw człowieka. Ponieważ sądy są jedną z instytucji władzy, kontrolerzy sejmowi są upoważnieni również do nadzorowania, jak sądy służą ludziom.

Patrząc na praktykę SKRL, trzeba też podkreślić, że Sąd Konstytucyjny akcentuje niezależność sądów od władzy: „Konstytucja zabrania władzy wykonawczej wtrącać się do sprawowania wymiaru sprawiedliwości, wpływać w jakikolwiek sposób lub oceniać pracę sądów w trakcie rozpatrywa-

${ }^{29}$ LR Konstitucija, „Valstybės žinios” 1992, nr 33-1014. 
nia spraw, a tym bardziej - wskazywać, jak ma być sprawowany wymiar sprawiedliwości" ${ }^{30}$. Jak wiadomo, kontrolerzy sejmowi nie są zaliczani ani do władzy wykonawczej, ani ustawodawczej, ani tym bardziej sądowniczej. Ta wyjątkowa właściwość rzecznika praw obywatelskich jest konieczna do zagwarantowania niezależności jego działalności. Jest to jeszcze jeden argument potwierdzający, że rzecznicy praw obywatelskich, jako nienależący do żadnej z trzech władz i jako niezależna instytucja, są odpowiednim podmiotem do badania działalności sądów i sędziów.

Warto zaakcentować również to, że niezależność nie jest wyjątkową cechą sądów, tzn. sądy nie powinny przypisywać zasady niezależności wyłącznie sobie i twierdzić, że powinna być zagwarantowana niezależność tylko sądów. Zasada niezależności jest uniwersalna i stosuje się nie tylko w odniesieniu do sądów, ale ważne jest to, że treść zasady niezależności, bez względu na to, wobec jakiej instytucji jest stosowana, w zasadzie jest niezmienna. To znaczy, że analizując zasadę niezależności, nie trzeba zapominać, że oprócz sądów istnieją też inne instytucje, wobec których stosowana jest ta zasada. Na przykład art. 118 Konstytucji gwarantuje niezależność prokuratorów: „Prokurator pełniący swoje funkcje jest niezależny i kieruje się tylko ustawą". Ale to nie znaczy, że kontrolerzy sejmowi nie badają działalności prokuratorów. Art. 12 Ustawy kontrolerów sejmowych głosi, że kontrolerzy sejmowi „badają skargi dotyczące działań prokuratorów, urzędników biorących udział w postępowaniu dochodowym, które naruszają prawa i wolności człowieka" ${ }^{31}$. Tak więc nawet zatwierdzona przez Konstytucję zasada niezależności nie oznacza, że daje ona prawo do nadużyć i naruszania praw człowieka.

\section{Zakończenie}

Szukaliśmy odpowiedzi na pytanie, czy ombudsman jest konkurentem sądu? Przeprowadzona analiza sugeruje odpowiedź negatywną. Po pierwsze sądy i rzecznicy praw obywatelskich należą do różnych władz państwowych. Po drugie sądy gwarantują prawa człowieka retrospektywnie i pasywnie, a ombudsmani - prewencyjnie i aktywnie. Można więc twierdzić, że działalność ombudsmanów i sądów odbywa się na różnych płaszczyznach, a to znaczy, że w takiej sytuacji nie może być konkurencji.

${ }^{30}$ Uchwała SKRL z dn. 13 grudnia $2004 \mathrm{r}$.

31 Ust. 3 art. 12 Ustawy kontrolerów sejmowych RL, Lietuvos Respublikos Seimo kontrolieriu įstatymas, „Valstybės žinios” 1998, nr 110-3024; 2004, nr 170-6238. 
Poza tym rzecznicy praw obywatelskich są upoważnieni do kontrolowania, czy sędziowie nie naruszają praw człowieka i w ten sposób mogą wpłynąć na zwiększenie autorytetu sądów i zaufania wobec nich. Uchwały Konstytucji i podane przez SKRL ich traktowanie wyraźnie wskazują na taki obowiązek kontrolerów sejmowych. To znaczy, że nie są potrzebne żadne poprawki do Konstytucji, które by miały zwiększyć zakres pełnomocnictw kontrolerów sejmowych, usunąć zastrzeżenie występujące w art. 73 Konstytucji na temat sędziów lub takie, w których byłyby uściślone jeszcze jakieś inne uchwały ustawy zasadniczej. Konstytucja nadaje kontrolerom sejmowym bardzo szerokie i ważne pełnomocnictwa (łącznie z upoważnieniem do badania działalności sędziów), których wykonanie warunkuje zagwarantowanie i urzeczywistnienie jednej z podstawowych zasad Konstytucji - zasady państwa prawa. Państwem prawa może być nazywane takie państwo, w którym sędziowie trzymają się aktów prawnych, rozpatrują sprawy w sposób odpowiedzialny, sędziowie stosownie traktują osoby biorące udział w sprawie, przestrzegają praw człowieka oraz takie, w którym działalność sądu jako trzeciej władzy jest nadzorowana przez niezależnego i bezstronnego obserwatora. W Republice Litewskiej takim obserwatorem jest kontroler sejmowy.

Wszystko to oznacza, że sądy i rzecznicy praw człowieka nie powinni ze sobą konkurować, ale współpracować. Mają oni bowiem ten sam cel - zagwarantowanie, aby prawa człowieka były szanowane i żeby ich przestrzegano. Pracując wspólnie i mając ten sam cel, można byłoby osiągnąć, żeby każda osoba odczuwała, że jej prawa są rzeczywiście skutecznie chronione przez dwóch niezależnych arbitrów - sąd i rzecznika praw obywatelskich. Wówczas każda osoba czułaby, że mieszka rzeczywiście w państwie prawa. 